\title{
Inheritance of Resistance to Foliar Infection by Xanthomonas axonopodis pv. dieffenbachiae in Anthurium
}

\author{
W. Elibox and P. Umaharan, Department of Life Sciences, Faculty of Science and Agriculture, the University of the \\ West Indies, St. Augustine Campus, St. Augustine Circular Road, St. Augustine, Republic of Trinidad and Tobago
}

\begin{abstract}
Elibox, W., and Umaharan, P. 2010. Inheritance of resistance to foliar infection by Xanthomonas axonopodis pv. dieffenbachiae in anthurium. Plant Dis. 94:1243-1247.

The inheritance of resistance to the foliar phase of bacterial blight disease, caused by Xanthomonas axonopodis pv. dieffenbachiae, in Anthurium andraeanum was studied using parentoffspring regression analysis. In all, 14 parental cultivars, each represented by 3 plants per replicate, and 12 biparental progenies derived from the parents, each represented by 20 plants per replicate, were evaluated for foliar resistance using a leaf-disc, vacuum infiltration method in a randomized complete block design with three replications over two seasons. Three to five leaf discs $\left(5.6 \mathrm{~cm}^{2}\right.$; stage-2 leaves) obtained from each plant were vacuum infiltrated (15 psi; $\left.10 \mathrm{~s}\right)$ with $10^{8} \mathrm{CFU} / \mathrm{ml}$ of inoculum and incubated $\left(30^{\circ} \mathrm{C}\right)$ in trays. The time taken for the lesion to cover the entire disc was recorded for each disc. The progeny distributions were normally distributed with considerable transgressive segregation. Midparent/offspring regression analysis showed a high narrow sense heritability of $0.89 \pm 0.13$. These results indicate that inheritance of foliar resistance to blight is quantitative, with a major role for additive genetic effects. A breeding strategy to combine resistance to bacterial blight at both the foliar and systemic levels is discussed.
\end{abstract}

Bacterial blight disease (blight) caused by Xanthomonas axonopodis pv. dieffenbachiae (26), previously known as $X$. campestris pv. dieffenbachiae (18), is the most important disease of Anthurium andraeanum (Hort.) (16). The disease was first reported in Brazil in 1960 and subsequently in Hawaii in 1971 (13). Blight was responsible for the decline of the Hawaiian anthurium industry in the 1980 s $(15,17,19)$ and the anthurium industry in the Caribbean in the 1990s (6).

Blight is easily transmitted, difficult to control (20), and spreads by excessive water splashing, movement through infected soil, or through contact with infected plant material and tools $(20,24)$. The pathogen can survive and remain pathogenic in leaf lamina, petiole, and root residues for as long as 4 months (5). Foliar infection occurs by pathogen entry into the leaves (24) via hydathodes (25) or wounds $(10,19)$.

The blight disease is characterized by water-soaked leaf spots with a dark center and a yellow halo; yellowing of older leaves and petioles caused the infected leaves and flowers to break off easily, revealing dark-brown streaks at their bases

Corresponding author: P. Umaharan

E-mail: pathmanathan.umaharan@sta.uwi.edu

Accepted for publication 21 June 2010.

doi:10.1094/PDIS-02-10-0091

(C) 2010 The American Phytopathological Society
(22); and leaf chlorosis (19). The disease has two phases, a foliar and a systemic phase $(8,10)$. In the foliar phase, the pathogen invades the foliage of the plant via hydathodes (25). In susceptible cultivars, the foliar infections can rapidly progress into a systemic phase, resulting in plant death.

Several physical and chemical measures to control the disease have been described (14,19-24) but they are expensive and require capital intensive structures and good management practices, such as daily removal of infected leaves, cut flowers, and plants (2). It is generally agreed that the most cost-effective approach to controlling blight in anthurium would be through the development of resistant cultivars $(2,24)$.

It has been well established that anthurium cultivars show differential susceptibility to the foliar and systemic phases of blight $(8,10)$. However, lack of reliable methods of effectively discriminating between the two phases of resistance has long impeded studies aimed at understanding the genetics of resistance and, consequently, hampered breeding programs. Hence, cultivars that were developed in the past often did not have commercially acceptable levels of resistance (1).

Screening methods capable of effectively discriminating between systemic (6) and foliar (8) phases of resistance to blight have recently been developed. Using these methods, sources of resistance to both systemic and foliar infection by blight have been identified in desired horticul- tural backgrounds $(6,8)$. More recently, a GFP-based screening approach for systemic resistance (6) has been used to describe the genetics of resistance, but only for systemic blight infection $(7,9)$. It is desirable to determine the genetic basis of resistance to blight infection at the foliar level because this would enable better exploitation of resistance to blight infection in anthurium breeding programs.

The objective of this study was to determine the genetic basis of resistance to foliar infection by the bacterial blight pathogen.

\section{MATERIALS AND METHODS}

Anthurium parents. Fourteen parental cultivars with varying levels of foliar resistance to blight and representing the entire range of variation for foliar resistance (8) were selected for the study (Table 1). The parents were planted in beds made of coconut husk and coconut coir in a shade house covered with $75 \%$ shade saran at both the top and along the sides. The study was conducted in a commercial anthurium farm, Kairi Blooms Ltd., situated in Arima, Trinidad.

Hybridization. In all, 12 biparental crosses (Table 1) involving the 14 parents (Table 2) were performed during the period of January to April 2000. Anthurium is protogynous and, hence, the spadix first goes through a female phase recognizable by the spadix becoming sticky to the touch, followed by a male phase when the spadix becomes covered with powder-like pollen. Previously isolated pollen-bearing

Table 1. Categorization of the 12 crosses involving the 14 Anthurium andraeanum (Hort.) cultivars used to evaluate the genetic basis for foliar resistance to bacterial blight

\begin{tabular}{ll}
\hline Cross & Cross type $^{\mathbf{a}}$ \\
\hline Cross 3962/Success & HS-R \\
Local Orange/Honduras & HS-R \\
Mirjam/Ibara & MS-HS \\
Acropolis/Cross 356 & R-R \\
Acropolis/Honduras & R-R \\
Champagne/Cross 3962 & MS-HS \\
Champagne/Honduras & MS-R \\
Champagne/Acropolis & MS-R \\
Local Orange/Venus & HS-MS \\
Local Whitish & MS-R \\
Pink/Pierrot & \\
Lydia/Cross 3962 & MS-HS \\
Acropolis/Victoria & R-MS \\
\hline
\end{tabular}

${ }^{\mathrm{a}} \mathrm{HS}=$ highly susceptible; $\mathrm{MS}=$ moderately susceptible; $\mathrm{R}=$ resistant. 
spadices from each male parent were harvested between 0600 and $0800 \mathrm{~h}$ and placed separately in labeled, clear plastic bags. A brush was used to transfer pollen obtained from spadices of one specific male parent to receptive spadices of a specific female parent, and each cross was labeled accordingly and isolated to prevent cross contamination. Each cross was made seven times to generate adequate seed per cross (at least 20 seeds). Pollinated spadices were covered with brown paper bags after pollination to prevent insect contamination.

Care of seedlings. After 6 to 7 months, the ripe (yellow) berries, each containing one to two green seeds, were collected and squeezed gently to remove the seeds. Seed were planted in labeled (name and sowing date) seedling trays containing peat moss (Premier Horticulture Ltd., Quebec, QC, Canada) and placed in the nursery house where average relative humidity and temperature were $89 \%$ and $28^{\circ} \mathrm{C}$, respectively (HOBO, England). The nursery house was covered with plastic and $75 \%$ shade saran to protect plants from sun and rain and was equipped with a mist irrigation and fertigation system. The seedlings were transplanted into labeled $8-\mathrm{cm}^{2}$ ( $8 \mathrm{~cm}$ deep) pots containing peat moss, 6 months after germination. After 1 year, the seedlings were transplanted into labeled $10.5-\mathrm{cm}^{2}$ (12.5 $\mathrm{cm}$ deep) pots containing peat moss and grown for another year before subject- ing them to screening for resistance to blight. The seedlings were watered every day for $10 \mathrm{~s}$ at 15-min intervals between 0900 and $1600 \mathrm{~h}$. The plants were fertilized $(0.45 \mathrm{~g} / \mathrm{pot})$ on a monthly basis with either triple super phosphate (Chemos $\mathrm{GmbH}$, Regenstauf, Germany) or 12-11-13 NPK (Norsk Hydro Olje AB, Nybro, Sweden). The $\mathrm{pH}$ of the growing media was maintained at 5.5 by continuous monitoring and applying calcium carbonate (limestone; TRINCARB, Port-of-Spain, Trinidad) as necessary. The nematicide Temik (Aldicarb, Shandong, China), was applied once to prevent nematode infestation.

Screening the population. The 14 parental cultivars along with their 12 biparental progenies ( $2 \frac{1}{2}$ to 3 years old) were screened for foliar resistance to blight using the optimized leaf-disc vacuuminfiltration method (8). The experiment was conducted first in the wet season (July to November; trial 1) and then repeated in the dry season (January to May; trial 2). The experiment was arranged in a randomized complete block design with three replications, each replication consisting of 3 plants each for the parents and 20 plants each for the biparental progenies. Replications were carried out over time. The second youngest (stage 2) leaf (10) from each of 20 biparental progenies per cross was harvested, surface sterilized with $70 \%$ ethanol, cut into leaf discs of $5.6 \mathrm{~cm}^{2}$ (diameter of $2.67 \mathrm{~cm}$ ) using a cork borer,

Table 2. Foliar resistance to bacterial blight, measured as time taken for lesion to cover the leaf disc (TLC) for 14 Anthurium andraeanum (Hort.) cultivars in trials 1 and 2

\begin{tabular}{lccc}
\hline & \multicolumn{3}{c}{ Mean TLC (days) } \\
\cline { 2 - 4 } Cultivar $^{\mathbf{a}}$ & Trial 1 & Trial 2 & Trials 1 and 2 \\
\hline Acropolis (R) & 18.0 & 16.4 & 17.2 \\
Champagne (MS) & 10.0 & 12.0 & 11.0 \\
Cross 356 (R) & 18.8 & 17.6 & 18.2 \\
Cross 3962 (HS) & 7.1 & 11.0 & 9.1 \\
Honduras (R) & 17.2 & 19.0 & 18.1 \\
Ibara (HS) & 5.1 & 9.0 & 7.1 \\
Local Orange (HS) & 6.0 & 10.0 & 8.0 \\
Local Whitish Pink (MS) & 10.4 & 12.3 & 11.4 \\
Lydia (MS) & 10.3 & 13.3 & 11.8 \\
Mirjam (MS) & 10.1 & 12.1 & 11.1 \\
Pierrot (R) & 14.7 & 18.0 & 16.4 \\
Success (R) & 17.0 & 16.0 & 12.6 \\
Venus (MS) & 11.0 & 14.1 & 11.5 \\
Victoria (MS) & 11.5 & 11.5 & $\ldots$ \\
Standard error & 0.84 & 1.02 & \\
\hline
\end{tabular}

${ }^{\mathrm{a}} \mathrm{R}=$ resistant, $\mathrm{MS}=$ moderately susceptible, and HS = highly susceptible.

Table 3. Analysis of variance using mean original infiltration area (OIA) as a covariate for mean time taken for lesion to cover the leaf disc per replicate for 12 Anthurium andraeanum Hort. crosses evaluated for resistance to foliar infection by bacterial blight disease in trials 1 and 2

\begin{tabular}{lrcccc}
\hline Source & DF & Sum of squares & Mean square & $\boldsymbol{F}$ ratio & Probability $^{\mathbf{a}}$ \\
\hline OIA & 1 & 1.760172 & 1.760172 & 0.95 & $0.334^{\mathrm{NS}}$ \\
Cross & 11 & 326.9228 & 29.72025 & 16.06 & $0.000^{* * *}$ \\
Trial & 1 & 32.01701 & 32.01701 & 17.3 & $0.000^{* * *}$ \\
Cross $\times$ trial & 11 & 43.35073 & 3.940976 & 2.13 & $0.036^{*}$ \\
Error & 47 & 86.9788 & 1.850613 & $\ldots$ & $\ldots$ \\
Total (adjusted) & 71 & 499.8042 & $\ldots$ & $\ldots$ & $\ldots$ \\
Total & 72 & $\ldots$ & $\ldots$ & $\ldots$ & $\ldots$ \\
\hline
\end{tabular}

a Probability level: $* * *$ and $*=$ significant at $P<0.001$ and 0.05 , respectively, and NS $=$ not significant. vacuum infiltrated (15 psi, $10 \mathrm{~s})$ with $10^{8}$ $\mathrm{CFU} / \mathrm{ml}$ of inoculum, and incubated in plastic trays lined with moist tissue paper. Each tray was covered with a plastic bag as previously described (8) and maintained at $30^{\circ} \mathrm{C}$. Five and three leaf discs per plant were inoculated in trial 1 and trial 2, respectively. Data were taken on the number of days for the lesion to cover the entire disc (TLC; 8). Mean TLC over the leaf discs inoculated was used in the analysis.

Data analysis. The original infiltration area (OIA) was determined for each inoculated disc by tracing it onto translucent paper and determining the leaf area of the cut-outs using a leaf area meter $(\Delta \mathrm{T}$ Area Meter MK2 model; Delta-T Devices, England). Analyses of variance (ANOVAs) were carried out on the TLC data obtained for both the parent cultivars and the progeny plants per cross using mean OIA as a covariate (NCSS 2001 version; Number Crunching Statistical Systems, Kaysville, UT) separately for the trial 1 and trial 2 experiments and for the two trials combined. Comparison of linear regression between genotypic performances in each trial versus genotypic means over trials was carried out using the COLR program (version 1; Caribbean Agricultural Research and Development Institute, 1974). The mean TLC for the parent cultivars as well as the mean TLC per cross based on the ANOVAs were recorded. A histogram was plotted for the number of progeny plants per cross whose TLC exceeded the better parental value (the TLC of the parent with the larger value between the two parents involved in a particular cross) or the midparent value (mean of the male and female parental TLC for the particular cross), separately for each trial. The Shapiro-Wilk W test (NCSS, 2001) was carried out for the progeny frequency distributions for each trial to determine whether or not the distributions were normal. The mean TLC per cross was subjected to a linear regression analysis against corresponding female parent, male parent, and midparental values for TLC, separately for trial 1 and trial 2, and together over the two trials (NCSS, 2001). The slope of the parent-offspring regression $(3,12)$ was used to obtain an estimate of narrow-sense heritability $\left(\mathrm{h}^{2}\right)$ separately for trial 1 and trial 2 and then for the combined data for both trials. Comparison of parent-offspring regression lines for trial 1 and trial 2 was carried out using the COLR program.

\section{RESULTS}

Trial differences in TLC. There were significant differences $(P<0.05)$ among the parents and progeny families with respect to TLC in both trial 1 and trial 2 based on an $F$ test. Although between-trial differences were significant $(P<0.001)$, block differences within trials were not significant $(P>0.05)$. Genotype-trial in- 
teraction was significant $(P<0.05)$ only for the progeny families but was small compared with the main effect (Table 3). A comparison of regression lines for the parents as well as progenies (genotypic performance in trial 1 versus genotypic mean over trial and genotypic performance in trial 2 versus genotypic means over trial) indicated that the regressions could be represented by two separate but parallel lines (data not presented). Cross 356, Acropolis, Honduras, Success, and Pierrot were the most resistant parental cultivars while Ibara, Local Orange, and Cross 3962 were the most susceptible in both trials (Table 2). The range between the most resistant and the most susceptible parental cultivar in trial 1 and trial 2 was 13.7 and 10.0 days, respectively; the average for the two trials was 11.1 days. Lesions eventually covered the leaf discs for all cultivars.

The range of variation in the progenies of all crosses in both trial 1 and trial 2 exceeded that of the parents. The progeny frequency distributions showed a continuous and generally normal distribution (Shapiro-Wilk W test: $P \geq 0.05$; Table 4), with transgressive segregation (Fig. 1A and B). All crosses in trial 1, with the exception of crosses Local Orange/Honduras and Local Orange/Venus, had some progenies whose TLC exceeded that of the better parent but all crosses had a significant proportion exceeding the midparent (Fig. 1A). All crosses in trial 2 had a proportion of the progenies whose TLC exceeded that of the better parent as well as the midparent values (Fig. 1B).

Correlations and parent-offspring regressions. Although the correlation coefficient between progeny TLC and female parent TLC $(r=0.64 ; P<0.05)$ as well as progeny TLC and male parent TLC $(r=$ $0.69 ; P<0.05)$ were significant, they were smaller than that for progeny and midparent TLC $(r=0.87 ; P<0.01)$ in trial 1 . Regression of progeny values on either parent was relatively weak (female parent:

Table 4. Probability values for the Shapiro-Wilk W test of normality for the progenies of $12 \mathrm{An}$ thurium andraeanum (Hort.) crosses evaluated for resistance to foliar infection by Xanthomonas axonopodis pv. dieffenbachiae in trials 1 and 2

\begin{tabular}{lcc}
\hline \multirow{2}{*}{ Cross } & \multicolumn{2}{c}{ Probability $^{\mathbf{a}}$} \\
\cline { 2 - 3 } & Trial 1 & Trial 2 \\
\hline Cross 3962/Success & 0.84 & 0.23 \\
Local Orange/Honduras & 0.14 & 0.14 \\
Mirjam/Ibara & 0.09 & 0.23 \\
Acropolis/Cross 356 & 0.41 & 0.08 \\
Acropolis/Honduras & 0.14 & 0.14 \\
Champagne/Cross 3962 & 0.26 & 0.42 \\
Champagne/Honduras & 0.08 & 0.40 \\
Champagne/Acropolis & 0.75 & 0.07 \\
Local Orange/Venus & 0.55 & 0.22 \\
Local Whitish Pink/Pierrot & 0.09 & 0.55 \\
Lydia/Cross 3962 & 0.07 & 0.05 \\
Acropolis/Victoria & 0.09 & 0.13 \\
\hline
\end{tabular}

a $P \geq 0.05$ for $\mathrm{W}$ implies that the distribution is normal.
$R^{2}=0.41$, slope of $0.53 \pm 0.202$; male parent: $R^{2}=0.48$, slope of $\left.0.52 \pm 0.171\right)$; but was strong on midparental values $\left(R^{2}=\right.$ 0.76 , slope of $0.90 \pm 0.159$; Fig. 2A). Furthermore, the slope of the regression line of midparental values was also not significantly different $(P<0.05)$ from 1 , based on a $t$ test.

The correlation coefficient between progeny TLC and female parent TLC in trial 2 was not significant $(r=0.49 ; P>$ $0.05)$. Although the correlation between mean progeny TLC and male parent TLC was significant $(r=0.66 ; P<0.05)$, it was considerably smaller than that for progeny TLC and midparent TLC $(r=0.82 ; P<$ $0.01)$. There was a strong regression $\left(R^{2}=\right.$ $0.68 ; P \leq 0.01)$ of progeny TLC on midparental TLC in trial 2, with a slope of $0.92 \pm 0.20$ (Fig. 2A).

The correlation between TLC for the 14 anthurium cultivars evaluated in trial 1 and trial 2 was large and significant $(r=0.93$;
$P<0.01)$. TLC for the 14 cultivars was, on average, 1.8 days longer in trial 2 compared with trial 1. Similarly, the correlation between midparent TLC in both trials was large and significant $(r=0.93 ; P<0.01)$. On average, midparent TLC in trial 2 was 1.7 days longer than in trial 1 . The correlation between mean progeny TLC in trial 1 and trial 2 was also significant at $P<0.05$ $(r=0.61)$. On average, mean progeny TLC in trial 2 was 4.8 days longer than in trial 1.

A comparison of linear regression lines for mean midparent TLC over trials versus mean progeny TLC in trial 1 and trial 2 showed that they can be represented as two parallel lines, suggesting that there was no genotype-trial interaction of the crossover type (Table 5). In general, the TLC was higher in trial 2 than in trial 1.

When TLC for the 12 cultivars and their progenies were grouped over trials, there was significant correlation between mean
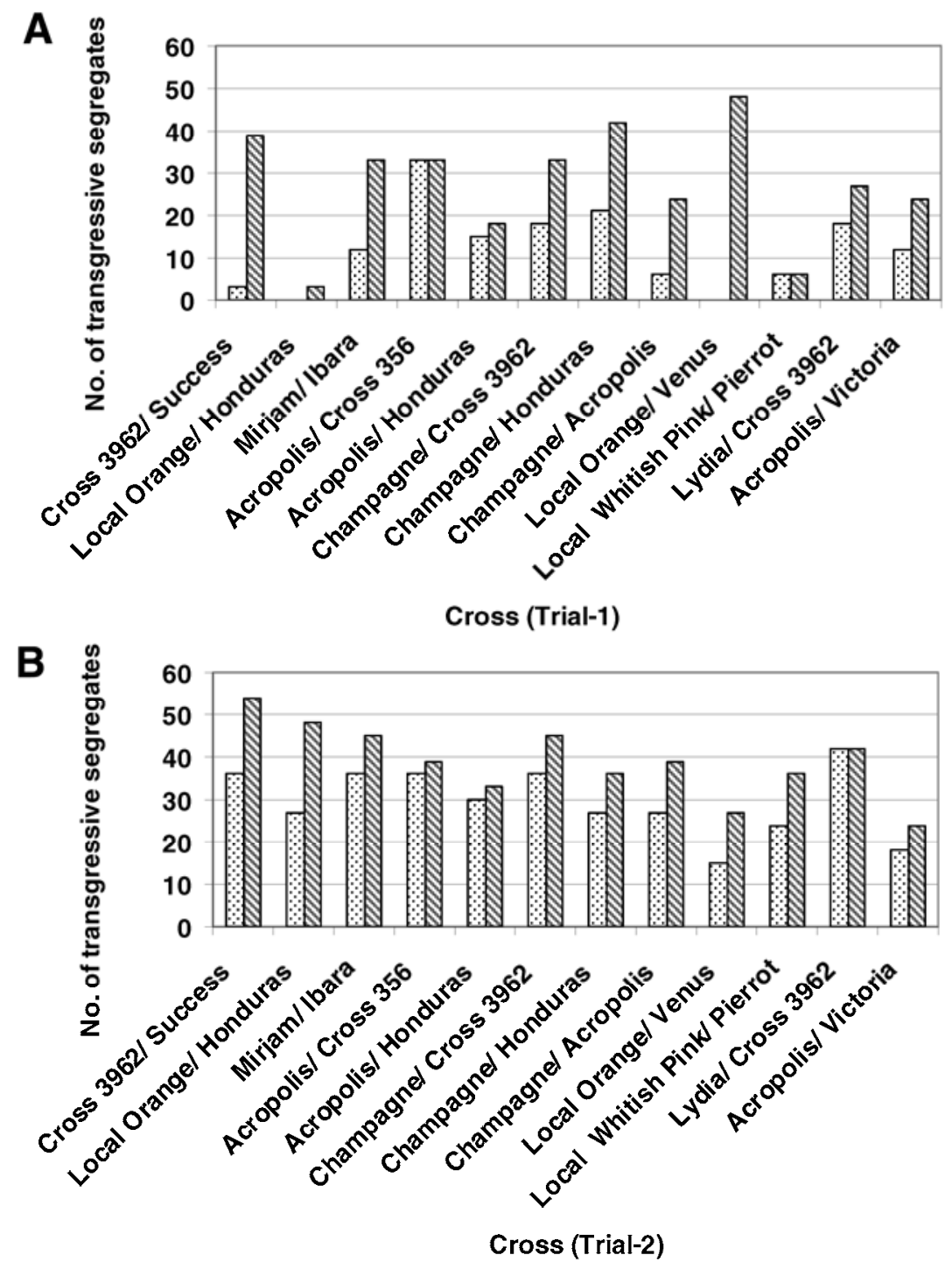

Fig. 1. Number of progeny plants per cross that had the time taken for the lesion to cover the entire disc (TLC; days) greater than the better parent TLC (dotted bar) or midparent TLC (downward diagonal bar) in 12 Anthurium andraeanum (Hort.) crosses evaluated for resistance to foliar infection by blight in $\mathbf{A}$, trial 1 and $\mathbf{B}$, trial 2. 
A

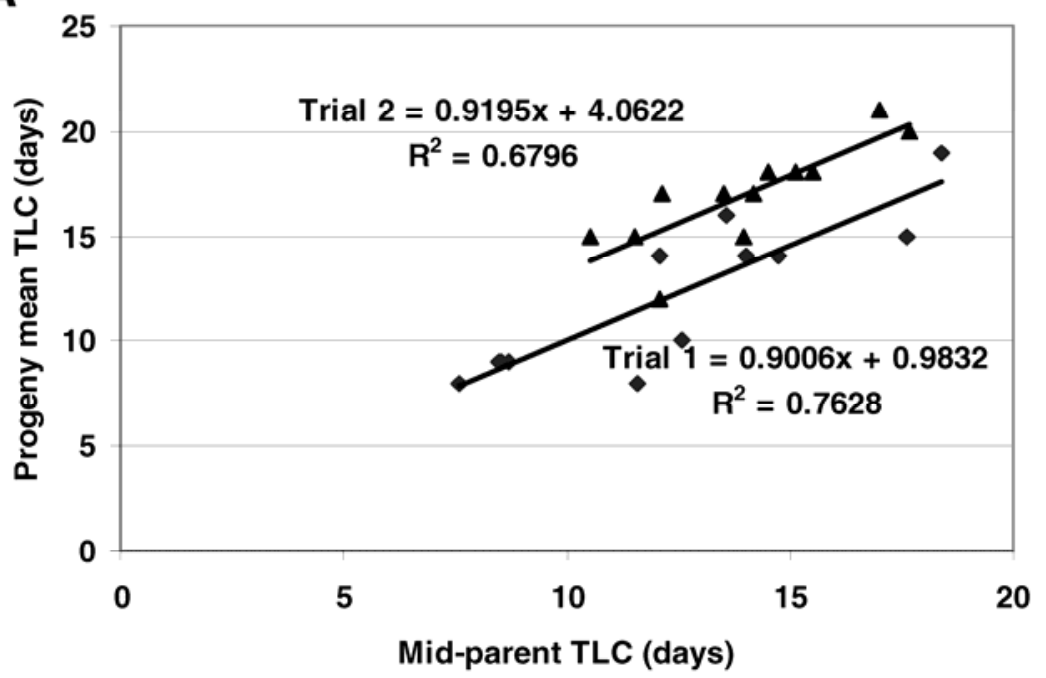

B

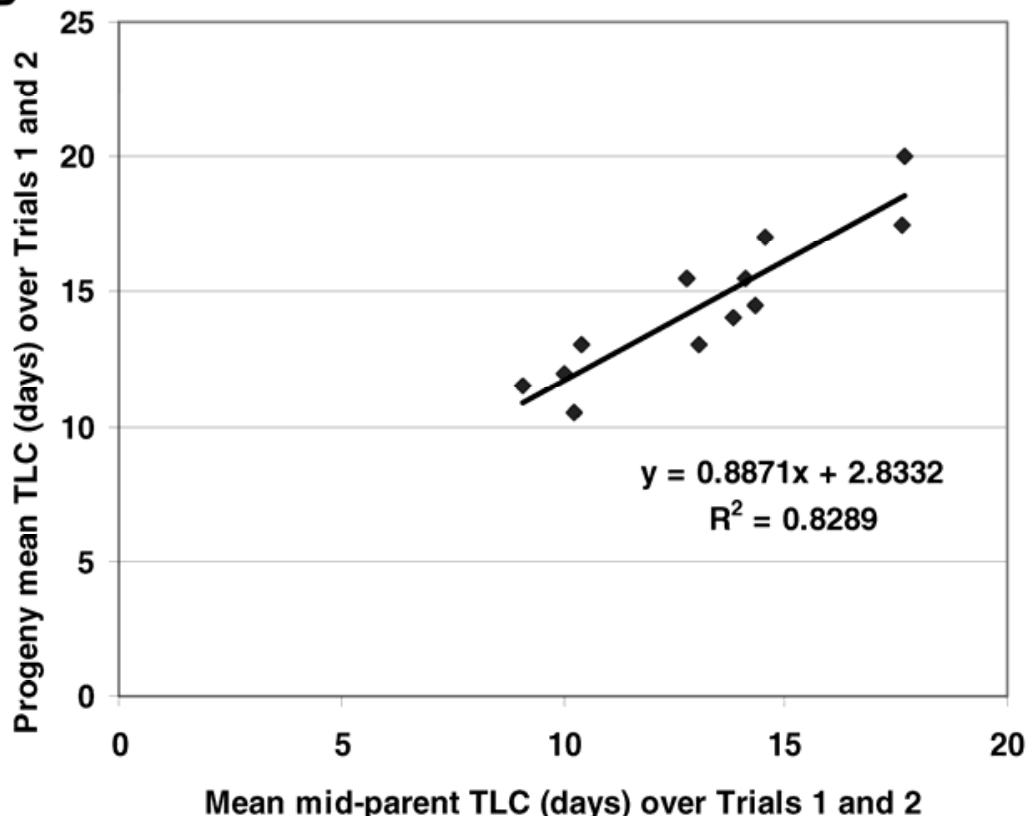

Fig. 2. Regression of progeny mean time taken for the lesion to cover the entire disc (TLC) on midparental TLC for 12 Anthurium andraeanum (Hort.) crosses evaluated for resistance to foliar infection by blight in A, trial 1 and trial 2 and $\mathbf{B}$, the two trials combined, based on the time taken for TLC. A, Standard error of mean progeny TLC is 0.63 and 0.97 in trial 1 and trial 2, respectively.

progeny TLC and female parent TLC $(r=$ 0.64; $P<0.05)$, male parent TLC $(r=$ $0.71 ; P<0.01)$, and midparent TLC $(r=$ $0.91 ; P<0.01)$. As before, the relationship between mean progeny TLC and either parent TLC was weak (female parent: $R^{2}=$ 0.41 , slope of $0.52 \pm 0.20$; male parent: $R^{2}$ $=0.50$, slope of $0.47 \pm 0.15)$ compared with mean progeny TLC and midparent TLC $\left(R^{2}=0.83\right.$, slope of $\left.0.89 \pm 0.13\right)$ (Fig. 2B). Again, the slope of the midparental regression line was not significantly different from 1 , based on a $t$ test.

\section{DISCUSSION}

The results of this study showed that parental, midparental, and mean progeny TLC values were, on average, larger in the dry season (trial 2) compared with the wet tion indicated that resistance to foliar infection by blight in anthurium is quantitative. In both trials, regression of mean progeny TLC on either the female parent or the male parent was weak but regression of the mean progeny TLC on the midparent values was strong and highly significant, suggesting a biparental mode of inheritance for this character $(3,12)$. The parallel lines for parent-offspring regressions obtained for trial 1 and trial 2 indicate that the slope and, hence, narrowsense heritability were not significantly different between trials. Further evidence of a major role for additive genetic effects can be seen from the transgressive segregation observed. In both trials, a large proportion of the progeny plants showed TLC values that exceeded that of the better parent TLC and the midparent TLC. The fact that foliar resistance to diseases caused by Xanthomonas spp. is polygenically inherited has also been shown in bacterial leaf blight resistance of rice caused by $X$. oryzae pv. oryzae (27) and resistance to the race-1 strain of $X$. campestris pv. vesicatoria in tomato (28).

The results of this study suggest that foliar resistance to blight can be improved readily by recurrent mass selection methods. The strong additive component (slope not significantly different from 1) suggests that phenotypic selection based on the screening method outlined in this study would be highly effective in identifying superior segregants (12). Further, the study shows that the number of transgressive segregants could be increased by appropriate parental choice and by increasing the population size.

Although the TLC was achieved slightly more rapidly in trial 1 than in trial 2 and there was evidence of a small but significant genotype-trial interaction based on ANOVA (Table 3), the ranking order of the genotypes (parent means or progeny means) did not change. This is evidenced by (i) the high correlation between parents as well as progeny TLC values between trial 1 and trial 2 and (ii) separate but parallel lines obtained for the two trials based on a comparison of regressions, indicating that the interactions are of the noncrossover type. Thus, genotype-environment interactions are unlikely to slow progress in breeding.

Resistance to blight has been shown to exist at two levels: (i) foliar resistance, which determines the extent of leaf damage attributed to blight; and (ii) systemic resistance, which determines the magnitude of plant death associated with blight infections (8). Systemic resistance to blight is determined by two dominant genes (9) with interallelic interaction, and it is evident from this study that resistance to foliar infection is quantitatively inherited, with a strong additive genetic component.

This work and previous studies $(6,8)$ have shown promising sources of resis- 
Table 5. Comparison of regression lines for trial 1 and trial 2 with respect to progeny mean time taken for lesion to cover the leaf disc (TLC) versus midparent TLC, in response to foliar infection by Xanthomonas axonopodis pv. dieffenbachiae in 12 Anthurium andraeanum (Hort.) crosses

\begin{tabular}{lrccc}
\hline Source & DF & Sum of squares & Mean square & Variance ratio $^{\mathbf{a}}$ \\
\hline Residual (pooled) & 20 & 68.0814 & 3.4041 & $\ldots$ \\
Between slopes & 1 & 7.3246 & 7.3246 & $2.15^{\text {NS }}$ \\
Residual (parallel lines) & 21 & 75.406 & 3.5908 & $\ldots$ \\
Between adjusted means & 1 & 140.1666 & 140.1666 & $39.04^{* * *}$ \\
Residual (overall) & 22 & 215.5726 & 9.7988 & $\ldots$ \\
Overall regression & 1 & 138.4273 & 138.4273 & $\ldots$ \\
Total & 23 & 353.9999 & $\ldots$ & $\ldots$ \\
\hline
\end{tabular}

a NS $=$ not significant and $* * *=$ significant at $P<0.001$.

Table 6. Comparison of foliar and systemic resistance to bacterial blight disease caused by Xanthomonas axonopodis pv. dieffenbachiae in 14 Anthurium andraeanum (Hort.) cultivars

\begin{tabular}{lccccc}
\hline & \multicolumn{2}{c}{ Foliar resistance $^{\mathbf{a}}$} & & \multicolumn{2}{c}{ Systemic resistance $^{\mathbf{b}}$} \\
\cline { 2 - 3 } \cline { 5 - 6 } Cultivars & Mean TLC (days) & Category & & TTD (weeks) & Proportion \\
\hline Acropolis & 17.2 & $\mathrm{R}$ & & - & 0.00 \\
Champagne & 11.0 & $\mathrm{MS}$ & & 9.0 & 1.00 \\
Cross 356 & 18.2 & $\mathrm{R}$ & & 9.0 & 1.00 \\
Cross 3962 & 9.1 & $\mathrm{HS}$ & & 10.3 & 1.00 \\
Honduras & 18.1 & $\mathrm{R}$ & & 10.5 & 0.44 \\
Ibara & 7.1 & $\mathrm{HS}$ & & - & 0.00 \\
Local Orange & 8.0 & HS & & - & 0.00 \\
Local Whitish Pink & 11.4 & MS & & 10.0 & 0.22 \\
Lydia & 11.8 & MS & & 7.7 & 1.00 \\
Mirjam & 11.1 & MS & & - & 0.00 \\
Pierrot & 16.4 & $\mathrm{R}$ & & 8.8 & 1.00 \\
Success & 16.5 & $\mathrm{R}$ & & 9.8 & 0.56 \\
Venus & 12.6 & MS & & 26.0 & 0.11 \\
Victoria & 11.5 & MS & & 8.8 & 1.00
\end{tabular}

a TLC = time taken for lesion to cover the leaf disc; category based on categorization from Elibox and Umaharan (8): $\mathrm{R}=$ resistant, $\mathrm{MS}=$ moderately susceptible, and HS = highly susceptible.

${ }^{\mathrm{b}}$ Data from Elibox and Umaharan (6). TTD = mean time to death, Proportion = proportion of plants that died, and - indicates that no plants died.

tance to both the systemic and foliar phases of infection to blight in anthurium. Hybridization of anthurium genotypes known for foliar and systemic resistance (Table 6) will result in progenies segregating for both phases of resistance. $\mathrm{Cv}$. Acropolis, which combines resistance to both foliar and systemic infection phases, is a useful parent in breeding for blight resistance at both levels. It is suggested that progeny identified for systemic resistance to blight using the method developed (6) be subjected to a second round of mass selection for foliar blight, so that the resulting progeny would have useful levels of resistance to both systemic and foliar phases of blight infection.

\section{ACKNOWLEDGMENTS}

This study was funded by the EUFORUM/CARIFORUM under the Caribbean Agricultural Technology Fund program. We thank the management and staff of Kairi Blooms Farm for providing the facilities for the research and $\mathrm{M}$. Goddard for technical assistance.

\section{LITERATURE CITED}

1. Alvarez, A. M., Norman, D., and Lipp, R. 1991. Epidemiology and control of anthurium blight. Pages 12-18 in: Proc. Hawaii Anthurium Ind. Conf., 4th. A. M. Alvarez, D. C. Deardorff, and K. B. Wadsworth, eds. HITAHR (Hawaii Inst. Trop. Agric. Human Resources) J. Ser. 04.06.91. University of Hawaii, Manoa, Honolulu.

2. Anaïs, G., Derrasse, A., Prior, P., and Cadic, A. 2000. Breeding anthuriums (Anthurium an-
11. Fukui, R., Fukui, H., and Alvarez, A. M.1999. Effect of temperature on the incubation period and leaf colonization in bacterial blight of anthurium. Phytopathology 89:1007-1014.

12. Hallauer, A. R., and Miranda, J. B. 1981 Quantitative Genetics in Maize Breeding. Iowa State University Press, Ames.

13. Hayward, A. C. 1972. A bacterial disease of anthurium in Hawaii. Plant Dis. Rep. 56:904908.

14. Higaki, T., Lichty, J. S., and Moniz, D. 1994. Anthurium culture in Hawaii. HITAHR (Hawaii Inst. Trop. Agric. Hum. Resour.) Res. Ext. Ser. 152.

15. Kamemoto, H. 1988. History and development of anthuriums in Hawaii. Pages 4-5 in: Proc. Anthurium Blight Conf., 1st. A. M. Alvarez, ed. HITAHR (Hawaii Inst. Trop. Agric. Hum. Resour.) J. Ser. 02.04.88. University of Hawaii, Manoa, Honolulu.

16. Kamemoto, H., and Kuehnle, A. R. 1996. Breeding Anthuriums in Hawaii. University of Hawaii Press, Honolulu.

17. Kamemoto, H., Kunisaki, J., Aragaki, M., and Higaki, T. 1986. Evaluation of anthurium accessions. HITAHR (Hawaii Inst. Trop. Agric. Hum. Resour.) Res. Ext. Ser. 069.

18. McCulloch, L., and Pirone, P. P. 1939. Bacterial leaf spot of Dieffenbachia. Phytopathology 29:956-962.

19. Nishijima, W. T. 1988. Anthurium blight: an overview. Pages 6-8 in: Proc. Anthurium Blight Conf., 1st. A.M. Alvarez, ed. HITAHR (Hawaii Inst. Trop. Agric. Hum. Resour.) J. Ser. 02.04.88. University of Hawaii, Manoa, Honolulu.

20. Nishijima, W. T. 1989. Current anthurium blight control recommendations. Pages 7-9 in: Proc. Anthurium Blight Conf., 2nd. J. A. Fernandez and W. T. Nishijima, eds. HITAHR (Hawaii Inst. Trop. Agric. Hum. Resour.) J Ser. 03.10.89. University of Hawaii, Manoa, Honolulu.

21. Nishijima, W. T., and Chun, M. 1991. Chemical control and anthurium blight. Pages 22-23 in: Proc. Hawaii Anthurium Ind. Conf., 4th. A. M. Alvarez, D. C. Deardorff, and K. B. Wadsworth, eds. HITAHR (Hawaii Inst. Trop. Agric. Hum. Resour.) J. Ser. 04.06.91. University of Hawaii, Manoa, Honolulu.

22. Nishijima, W. T., and Fujiyama, D. K. 1985. Bacterial blight of anthurium. University of Hawaii Coop. Ext. Serv. Commodity Fact Sheet AN4:1-3

23. Norman, D. J., and Alvarez, A. M. 1996 Monitoring the spread of Xanthomonas campestris pv. dieffenbachiae introduced from symptomless anthurium cuttings into production fields. J. Am. Soc. Hortic. Sci. 121:582585.

24. Prior, P., Hostachy, B., Sunder, P., and Rott, P. 1985. Bacterial blight (X. campestris pv. dieffenbachiae) and bacterial leaf spot (Pseudomonas sp.) of anthurium in the French West Indies. Agron. Trop. 42:61-68.

25. Sakai, D. S. 1990. The effect of nitrate and ammonium fertilizer on the contents of anthurium guttation fluid. Pages 18-19 in: Proc. Anthurium Blight Conf., 3rd. A. M. Alvarez, ed. HITAHR (Hawaii Inst. Trop. Agric. Hum. Resour.) J. Ser. 05.07.90. University of Hawaii, Manoa, Honolulu.

26. Vauterin, L., Hoste, B., Kersters, K., and Swings, J. 1995. Reclassification of Xanthomonas. Int. J. Syst. Bacteriol. 45:472-489.

27. Washio, O., Kariya, K., and Toriyama, K 1967. Studies on breeding rice varieties for resistance to bacterial leaf blight. Bull. Chugoku Natl. Agric. Exp. Stn. 13:55-85.

28. Yu, Z. H., Wang, J. F., Stall, R. E., and Vallejos, C. E. 1995. Genomic localization of tomato genes that control a hypersensitive reaction to Xanthomonas campestris pv. vesicatoria (Doidge) Dye. Genetics 141:675-682. 